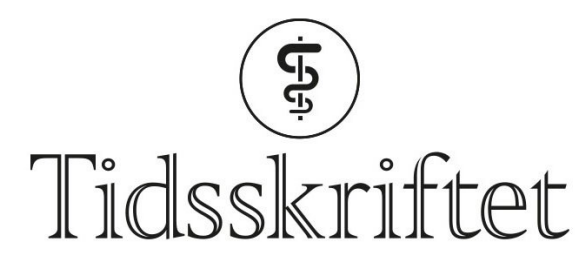

DEN NORSKE LEGEFORENING

\title{
Per Andersen
}

MINNEORD

LEIF GJERSTAD

VIDAR JENSEN

IVER ARNE LANGMOEN

TERJE LØMO

EDVARD INGJALD MOSER

MAY-BRITT MOSER

JOHAN FREDERIK STORM

JON STORM-MATHISEN

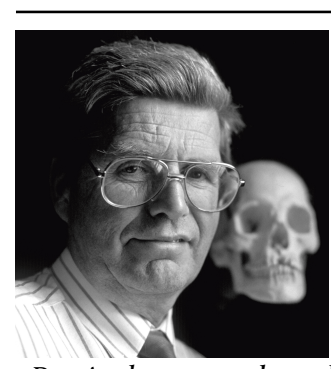

"Per Andersen avslører hjernen»

- bilde fra forsiden av

Aftenposten lørdag aften 9. april

1988, der Per Andersen ble

intervjuet om hukommelse og

laering $i$ anledning den nye

forskningsprisen fra

Forskningsrådet med fem års

bevilgning til undersøkelser av

hukommelsesprosessene. Foto:

Tor G. Stenersen, Aftenposten,

gjengitt med tillatelse.

En epoke er over med Per Andersens død, 17.2.2020, 90 år gammel. «Nye generasjoner leger 
og forskere trenger å få vite om og bli inspirert av hans store betydning, ikke bare som internasjonalt berømt hjerneforsker, men også som utrettelig og dyktig formidler og inspirator», sier Tidsskriftets sjefredaktør Are Brean.

Per Andersens virke spente fra nevrofysiologiens barndom i 1950-årene, da han var med å etablere elektrofysiologisk kartlegging av hjernens nervenettverk, «elektroanatomi», med lokalisering av inhibitoriske og eksitatoriske synapser på nervecellene, til mekanismer for læring på synapsenivå og funksjonelle virkninger av molekylære endringer i nevrotransmitterreseptorer og andre membranproteiner på 200o-tallet. The Royal Society sier det slik: «... his discoveries shaped our understanding of neural circuitry» (1).

Per Oskar Andersen ble født i Oslo 12.1.1930 og var eldst av fire søsken. Begge foreldrene innprentet i ord og gjerning at kunnskap er avgjørende, og sørget for at alle barna fikk god utdannelse. Per begynte på medisinstudiet ved Universitetet i Oslo hvor han som prosector minor ved Anatomisk institutt ble satt til å veilede andre studenter og tok sine første skritt mot en stor karriere i hjerneforskning.

Pers doktorgradsarbeid ble utført ved Nevrofysiologisk laboratorium, opprettet ved Anatomisk institutt av Birger Kaada i 1950-årene, under instituttbestyrer Jan B. Jansens inkluderende, fremsynte og faderlige åsyn. Bakgrunnen i den såkalte Oslo-skolen $\mathrm{i}$ nevroanatomi, grunnlagt av Jan B. Jansen og Alf Brodal og toneangivende i utforskingen av hjernens oppbygning gjennom det meste av det 20. århundre, gav Per en egen tilnærming til å forstå funksjon. Viktig var Theodor Blackstads arbeider om nerveforbindelsene $\mathrm{i}$ hippocampus (en del av hjernebarken) og hvordan nervebanene ender i atskilte soner. Pers avhandling var av den gamle skolen med en serie én-forfatters-originalartikler, «Interhippocampal Impulses I-IV», publisert i Acta Physiologica Scandinavica i 1959-6o. Den har satt mønster for ettertiden i tolkningen av hvordan elektriske felt brer seg i nervevevet, og i forståelsen av kommunikasjon mellom ulike deler av hjernen.

Etter doktordisputas i juni 1960 oppsøkte Per det internasjonalt fremste forskermiljøet. Med hjelp av Jansen og Brodal fikk han innpass hos Sir John C. Eccles i Australia, samt et Rockefeller Fellowship, og hele familien Andersen fløy til Canberra. Det ble to forrykende år fra 1961 til 1963- heldagseksperimenter med Eccles to ganger i uka fra åtte om morgenen til to om natta, og åtte artikler i Nature. Mens Per var der, fikk Eccles nobelprisen for klarlegging av synaptiske mekanismer, basert på fors $\varnothing \mathrm{k}$ utført i ryggmargen. Samarbeidet med Per førte Eccles inn på studier av selve hjernen. Blant annet viste de at inhibitoriske synapser fra kurvcelle-aksoner, strategisk plassert på cellelegemene til pyramideceller, kontrollerer signalene som går ut av hjernebarken. Dette var første gang et inhibitorisk nevron og dets synapser var identifisert i hjernen. Resultatene ble publisert i Nature i 1963, og i samme nummer etterfulgt av en artikkel av Blackstad som viste de inhibitoriske synapsene elektronmikroskopisk. I en ny Nature-artikkel senere samme år viste Andersen og Eccles at et liknende prinsipp gjelder i lillehjernen (et annet område hvor Per brakte spisskompetanse fra Oslo). Da Per kom hjem i 1963 og holdt seminar om Canberraoppholdet, sa han: "Jeg lærte mye fysiologi, og så lærte jeg bort en del anatomi.» Senere sa Eccles (til Roger A. Nicoll): «Per helped navigate me through the foramen magnum!» Tilbake i Oslo etablerte Per sin egen forskergruppe og ledet an i oppbyggingen av Nevrofysiologisk institutt (nå en del av Institutt for medisinske basalfag) ved Universitetet $\mathrm{i}$ Oslo. Han ble prosektor (førsteamanuensis) i 1963, dosent i 1968 og professor i 1972, til han i 2000 gikk av med pensjon og fikk emeritusstatus. Viktige bidrag fra Pers gruppe handler om i) funksjonelle nerveforbindelser og nettverk, inkludert lokalisasjon og struktur av eksitatoriske nerveterminaler i hippocampus (2), ii) plastiske endringer i synapsenes styrke, særlig aktivitetsindusert langtidspotensiering (long term potentiation, LTP, oppdaget av Terje Lømo i Pers laboratorium i 1966) (3-5), og iii) hippocampus-skivepreparatet til in vitro-utforskning av nervecellers virkemåte (6), basert på Pers oppdagelse av at hovedprojeksjonene av nervefibre, the trisynaptic circuit, er ordnet i lameller på tvers av hippocampus' lengderetning (7), slik at forbindelsene kan bevares innenfor en tynn 
transversal skive (longitudinelle projeksjoner forbinder skivene in vivo). Dette preparatet er fortsatt et sentralt verktøy i nevrofysiologien, og man glemmer hvilken radikal idé og nyvinning det representerer. Langtidspotensiering er nå etablert som grunnlag for læring og hukommelse og tema for et stort forskningsfelt, hvor Per hadde en lederrolle. Arbeidene om nerveforbindelser er viktige forutsetninger for blant annet den nobelprisbelønte oppdagelsen til Edvard Moser og May-Britt Moser av gitterceller i hippocampus-regionen. Innsikt fra disse og andre studier med utgangspunkt hos Per formet utviklingen av moderne nevrofysiologi og har blitt stående som grunnpilarer i fagfeltet (1). Det er også interessant å lese hans egne tanker om sitt liv som forsker (8).

På flere av de opprinnelige publikasjonene var Per Andersen ikke medforfatter. Dette kan synes overraskende i dag, men etter tradisjonen den gang var ikke gruppeleder alltid medforfatter, selv om han hadde gitt veiledning og lagt grunnen for forskningsaktiviteten og ideene. Pers lederstil hadde mønster fra Jan B. Jansen, med stor frihet under ansvar, hvor ansvaret lå i den uskrevne regel om å bruke sine evner til fulle. Resultatet var et entusiastisk, kreativt og egalitært miljø med stor grad av selvstendighet for den enkelte. Samtidig sørget Per for fokus på kritisk tenkning, sunn skepsis, intense diskusjoner og krav til kvalitet. Og, når Per hadde akseptert deg som elev og medarbeider, kunne du regne med hans fulle støtte. Eric Kandel (nobelprisvinner i 200o) skriver: «He was one of the great leaders of our field and he mentored many people who are now contributing importantly to brain science. His loss will be felt for a long time by many of us.»

Pers smittende entusiasme og omfattende innsikt gjorde ham til en ettertraktet aktør i internasjonale fora og skaffet ham et stort kontaktnett av fremragende hjerneforskere over hele verden. Han hadde en viktig rolle i etableringen av det nevrovitenskapelige forskningssamarbeidet i Europa, blant annet i opprettelsen av Federation of European Neuroscience Societies (FENS), European Journal of Neuroscience og EU-program. Per var kanskje mer kjent og anerkjent i utlandet enn i norske forskningskretser. Selv satte han enorm pris på å være en del av den verdensomspennende «familien» av likesinnede kunnskapssøkende. Han hadde et sosialt hjerte, og sammen med sin kone Kari inviterte han hjem til seg og til hytta i Hemsedal - eller til seiltur i en havgående båt han hadde bygd selv fra bunnen. Han tok verdens fremste forskere med på ski og innviet dem i norske tradisjoner. Denne gjestfriheten satte sine spor og var inspirerende både for gjestene og for Pers egne studenter, som ble inkludert i nettverket. Per ble døråpneren ut i verden.

Per var nysgjerrig hele livet. Han gledet seg over å oppdage hvordan alt er og virker, og over det hans elever fikk til. Han var rettskaffen og alltid klar til å stå opp for den som ble offer for urett. Per hadde også konkurranseinstinkt, og han passet på å feire suksessene. Når en artikkel var akseptert, kom sherryglassene frem. Det var klart hva han forventet. Da instituttet flyttet fra Karl Johans gate til Gaustad i 1990, var internkonkurransen å bli først til å få resultater i de nye laboratoriene. «Og vi må alltid slå svenskene», sa han, slo nevene kraftig sammen og satte latterdøra på vidt gap. Men han var faktisk glad i svenskene, og det var gjensidig. Tomas Hökfelt skriver: «Han var en ovanligt fin människa, en briljant forskare och en karismatisk föreläsare. Han var väldigt generös mot oss här på KI [Karolinska Institutet]. Ställde alltid upp när Sten [Grillner] och jag hade våra forskarutbildningskurser. Och studenterna älskade honom. Så vi alla såg Per som en kär vän.»

Per var et forbilde også når det gjelder å popularisere medisinsk kunnskap for allmennheten. Han ble kjent for hele Norge med sin NRK-serie i 1980 om «Din fantastiske hjerne» i samtale med Per Øyvind Heradstveit. Han var en ressurs for media og stilte villig opp som høyt skattet foredragsholder i mange ulike fora.

Mange anerkjennelser ble Per Andersen til del, slik som forskningspriser (Anders Jahres pris for yngre medisinske forskere 1967, Fridtjof Nansens belønning for fremragende forskning 1972, Forskningsrådets pris 1988, Fondation Ipsen Neuronal Plasticity Prize 1993, Eric K. Fernströms nordiska pris 1995, Lundbeckfondens forskerpris 1996), æresdoktorater (Universität Zürich 1988, Karolinska Institutet 1998) og innvalg i vitenskapsakademier 
verden over (Det Norske Videnskaps-Akademi 1980, Det Kongelige Norske Videnskabers Selskab 1988, Academia Europaea 1989, Kunglega Vetenskapsakademien 1991, National Academy of Sciences 1994, The Royal Society 2002). Han var Kommandør av Den Kongelige Norske St. Olavs Orden (1997).

Per var syk mot slutten av livet, men fikk pleie hjemme, hvor han delte måltider og musikk med Kari, som sto ved hans side i 65 år. Per og Kari fikk fire barn og seks barnebarn, som de var veldig stolte av.

Per var en fenomenal inspirator og rollemodell. En så engasjert, inspirerende, djerv og visjonær mann er det ikke mange unt å få møte. Vi fikk, og det er vi så uendelig takknemlige for. Nå er han borte, og vi sitter igjen med minnene om en stor mann. Per var en kjempe i norsk og internasjonal vitenskap, og han spilte en avgjørende rolle i den sterke posisjonen Norge har fått innenfor hjerneforskning.

Sitat i teksten uten angitt kilde er personlige meddelelser til Jon Storm-Mathisen.

På vegne av Per Andersens elever.

LITTERATUR:

1. The Royal Society. Per Andersen. https://royalsociety.org/people/per-andersen-10994 Lest 19.4.2020.

2. Andersen P, Blackstad TW, Lömo T. Location and identification of excitatory synapses on hippocampal pyramidal cells. Exp Brain Res 1966; 1: 236-48. [PubMed][CrossRef]

3. Lømo T. Frequency potentiation of excitatory synaptic activity in the dentate area of the hippocampal formation (XII Scandinavian Congress of Physiology, Turku 1966). Acta Physiol Scand 1966; 68 (suppl 277): 128.

4. Bliss TV, Lømo T. Long-lasting potentiation of synaptic transmission in the dentate area of the anaesthetized rabbit following stimulation of the perforant path. J Physiol 1973; 232:331-56. [PubMed][CrossRef]

5. Andersen P. Long-lasting facilitation of synaptic transmission. Ciba Found Symp 1977; 87-108. [PubMed]

6. Skrede KK, Westgaard RH. The transverse hippocampal slice: a well-defined cortical structure maintained in vitro. Brain Res 1971; 35: 589-93. [PubMed][CrossRef]

7. Andersen P, Bliss TV, Lømo T et al. Lamellar organization of hippocampal excitatory pathways. Acta Physiol Scand 1969; 76: 4A-5A. [PubMed]

8. Andersen P. Per Andersen. I: Squire LR, red. The History of Neuroscience in Autobiography. San Diego, CA: Academic Press 2004: 2-38.

Publisert: 15. juni 2020. Tidsskr Nor Legeforen. DOI:10.4045/tidsskr.20.0353

(C) Tidsskrift for Den norske legeforening 2020. Lastet ned fra tidsskriftet.no 